\title{
TU/e EmonONEN

\section{An analysis of coating-efficiency as a measure for capillary column performance}

\section{Citation for published version (APA):}

Cramers, C. A. M. G., Wijnheijmer, F. A., \& Rijks, J. A. (1979). An analysis of coating-efficiency as a measure for capillary column performance. Chromatographia, 12(10), 643-646. https://doi.org/10.1007/BF02302939

DOI:

10.1007/BF02302939

Document status and date:

Published: 01/01/1979

\section{Document Version:}

Publisher's PDF, also known as Version of Record (includes final page, issue and volume numbers)

\section{Please check the document version of this publication:}

- A submitted manuscript is the version of the article upon submission and before peer-review. There can be important differences between the submitted version and the official published version of record. People interested in the research are advised to contact the author for the final version of the publication, or visit the $\mathrm{DOI}$ to the publisher's website.

- The final author version and the galley proof are versions of the publication after peer review.

- The final published version features the final layout of the paper including the volume, issue and page numbers.

Link to publication

\section{General rights}

Copyright and moral rights for the publications made accessible in the public portal are retained by the authors and/or other copyright owners and it is a condition of accessing publications that users recognise and abide by the legal requirements associated with these rights.

- Users may download and print one copy of any publication from the public portal for the purpose of private study or research.

- You may not further distribute the material or use it for any profit-making activity or commercial gain

- You may freely distribute the URL identifying the publication in the public portal.

If the publication is distributed under the terms of Article 25fa of the Dutch Copyright Act, indicated by the "Taverne" license above, please follow below link for the End User Agreement:

www.tue.nl/taverne

Take down policy

If you believe that this document breaches copyright please contact us at:

openaccess@tue.nl

providing details and we will investigate your claim. 


\title{
An Analysis of Coating-Efficiency as a Measure for Capillary Column Performance
}

\author{
C. A. Cramers* / F. A. Wijnheijmer/J. A. Rijks \\ * Laboratory of Instrumental Analysis, Eindhoven University of Technology, P.O. Box 513, 5600 MB Eindhoven, \\ The Netherlands
}

\section{Key Words}

Plate height equations

Coating-effeciency

Capillary columns

\section{Summary}

An expression is proposed for the value of the CoatingEfficiency C.E. starting from the Golay-equation, extended to situations of appreciable pressure drop by Giddings. A comparison is made between the coatingefficiency following this theory and the simplified expression for coatingefficiency as generally used in the literature, that neglects the effects of resistance to mass transfer in the liquid phase and the pressure drop. It is shown that the complete equation from the coatingefficiency explains the observations made in practice. Application of the theory described will lead to a better check on film formation in capillary columns.

\section{Introduction}

One of the aspects of describing column quality is the comparison of experimentally obtained plate numbers with theoretically predicted values. In capillary gas chromatography it has become common practice to use the Caating-Efficiency "C.E." as a measure for this purpose. C.E. is defined as the ratio of theoretical to experimental plate height at optimum conditions:

$$
\text { C.E. }=\left(\frac{\mathrm{H}_{\text {theor }}}{\mathrm{H}_{\exp }}\right)_{\text {min }}
$$

In practice, however, the following simplifications are made in the Golay-Giddings [2,3] equation describing the theoretical plate height:

- the effect of a pressure gradient on peak broadening is neglected;
- it is assumed that the contribution of the resistance to mass transfer in the gas term is appreciably larger than the term accounting for diffusion in the stationary phase $\left(C_{m, 0} \geqslant C_{s}\right)$.

( $\mathrm{C}_{\mathrm{m}, 0}$ is defined at column outlet pressure conditions.)

This together with the Golay equation [2] leads to the well known expression:

$$
\text { C.E. }=\frac{r \sqrt{\frac{11 k^{2}+6 k+1}{3(1+k)^{2}}}}{H_{\text {exp, } \min }}
$$

$r$ being column radius

$k$ capacity ratio of a solute.

A study of experimental data, however, reveals the failure of eq. (2) to explain the following observations:

- C.E. is dependent on the nature of the carrier gas and the ratio of inlet to outlet pressure;

- the effect of the partition coefficient $K$ (and thus $k$ ) of a solute on the C.E. is different from the results predicted;

- wide bore columns show much better C.E.'s than narrow bore columns;

- stainless steel capillary columns and "whisker" columns show appreciably lower C.E.'s than smooth wall glass capillary columns under similar experimental conditions.

It is the aim of this paper to discuss the Coating-Efficiency from a theoretical point of view.

It will be demonstrated why and to what extent the simplified expression for C.E. as given by eq. (2) fails as a measure for column quality in many practical situations.

\section{Theory}

In a separate paper on the efficiency of capillary columns [1] the authors treated the dependence of optimum gas chromatographic conditions on inlet and outlet pressure, $P$, and the ratio of $C_{s} / C_{m, 0}$. It was shown that even when the liquid phase is distributed as an uniform film, $\mathrm{C}_{s}$, can 
seldom be neglected compared to $C_{m, 0}$. Especially in narrow bore columns it is necessary to include the ratio of inlet to outlet pressure, $P$, and the $C_{s}$ term in the calculations of $\mathrm{H}_{\text {theor,min }}$.

In the paper mentioned above [1] it was derived that starting from the Golay equation extended by Giddings to situations of appreciable pressure drop, in almost all practical situations the value of $\mathrm{H}_{\text {theor,min }}$ in the numerator of eq. (1) can be expressed as:

$$
\mathrm{H}_{\text {theor, } \min }=2 \sqrt{\mathrm{B}_{0} \mathrm{f}_{1}\left(\mathrm{C}_{\mathrm{m}, 0} \mathrm{f}_{1}+\mathrm{C}_{\mathrm{s}} \mathrm{f}_{2}\right)}
$$

$\mathrm{B}_{0}$ is the term of the Golay equation describing longitudinal molecular diffusion under conditions of column outlet pressure

$\mathrm{B}_{0} \quad=2 \mathrm{D}_{\mathrm{m}, 0}$

$D_{m, 0}$ is molecular diffusion coefficient of a solute in the carrier gas at column outlet pressure

$f_{1}$ and correct for effect of pressure gradient on column and efficiency.

$f_{2}$

$$
\begin{aligned}
& \mathrm{f}_{1}=\frac{9}{8} \frac{\left(\mathrm{P}^{4}-1\right)\left(\mathrm{P}^{2}-1\right)}{\left(\mathrm{P}^{3}-1\right)^{2}} \\
& \mathrm{f}_{2}=\frac{3}{2} \frac{\mathrm{P}^{2}-1}{\mathrm{P}^{3}-1}
\end{aligned}
$$

By definition, $P$, is the ratio of inlet to outlet pressure $=P_{i} / P_{0}$. In the following the C.E. obtained from the simplified eq. (2) and resulting from the complete form following eq. (3) will be compared:

Dividing C.E., using the complete eq. (3) as the numerator and the simplified form given by eq. (2) in the denominator yields:

$$
\frac{\text { C.E. (3) }}{\text { C.E. (2) }}=f_{1} \sqrt{1+G(k) \frac{f_{2}}{f_{1}}}
$$

In this expression the following symbols are used:

$$
\begin{aligned}
G(k)= & 4 a^{2} \frac{D_{m, 0}}{D_{s}} \cdot \frac{k}{11 k^{2}+6 k+1}= \\
& 4 a^{2} \frac{D_{m, 0}}{D_{s}} \cdot f(k)
\end{aligned}
$$

$D_{s}$ is diffusion coefficient of a solute in stationary liquid phase

$\mathrm{a}=\frac{V_{s}}{V_{m}}$ is volumetric phase ratio of stationary and mobile

If the stationary liquid film is distributed as an uniform film, a, can be replaced by

$$
\mathrm{a}=\frac{2 \mathrm{~d}_{\mathrm{f}}}{\mathrm{r}}
$$

$d_{f} \quad$ being film thickness.

\section{Results and Discussion}

Table I gives the variation of the pressure gradient correction factors $f_{1}$ and $f_{2}$ with the inlet to outlet pressure ratio. More difficult to estimate is the contribution of $G(k)$ in eq. (7), especially owing to a lack of data on $D_{s}$ in different stationary phases.

As an example data on $\mathrm{nC}_{4}-\mathrm{nC}_{9}$ hydrocarbons are taken from Desty [4]. From this publication it appears that $\frac{D_{m, 0}}{D_{s}} \simeq 5 \times 10^{4}$ for these hydrocarbons separated on squalane at $50^{\circ} \mathrm{C}$. The carrier gas was nitrogen, the outlet pressure 1 bar.

$\mathrm{f}(\mathrm{k})$ (eq. (9)) is easy to calculate [1]. At low values of $k$, $f(k)$ is proportional to $k$. On increasing $k, f(k)$ rises and passes through a maximum. At high values of $k, f(k)$ is given by $f(k)=1 / 11 \mathrm{k}$. The position of the maximum is easily found by differentiation of $f(k)$. The maximum value of $f(k)$ is 0.0791 for $k=0.3015$.

In Tables II and III ratios of C.E. according to eq. (3) and C.E. calculated by the generally accepted eq. (2) are given for several conditions. This ratio is, according to the definition of the Coating-Efficiency, of course also equal to:

$$
\frac{\text { C.E. (3) }}{\text { C.E. (2) }}=\frac{H_{\text {theor, } \min }(3)}{H_{\text {theor,min }}(2)}=\frac{2 \sqrt{B_{0} f_{1}\left(C_{m, 0} f_{1}+C_{s} f_{2}\right)}}{2 \sqrt{B_{0} C_{m, 0}}}
$$

This ratio is calculated for $n$-hydrocarbons under conditions as mentioned above, for different column diameters and different values of film thickness $\left(d_{f}\right)$. Assuming the disiribution of the liquid film to be homogeneous the phase ratio, a, easily follows from eq. (9). It should be noticed that for situations, often met in practice, where there is droplet formation of liquid phase, or if most stationary liquid is accomodated in pores of the column wall $\mathrm{CE}(3)$ | $\mathrm{CE}$ (2) will be appreciably larger than given in Tables II and III. This follows from the fact that $\mathrm{C}_{s}$ is proportional to $d_{f}^{2}$. If there is a non uniform film distribution of the liquid phase, $\mathrm{C}_{\mathrm{s}}$ will be larger, than for a uniform film, since $\mathrm{C}_{\mathrm{s}}$ will be determined mainly by spots within the column with the largest value of $d_{f}$.

Table I. Variation of pressure gradient correction factors with ratio, $P$, of inlet to outlet pressure.

\begin{tabular}{|c|c|c|c|}
\hline$P=P_{i} / P_{0}$ & $f_{1}$ & $f_{2}$ & $f_{2} / f_{1}$ \\
\hline 1.1 & 1.001 & 0.952 & 0.950 \\
1.5 & 1.013 & 0.790 & 0.779 \\
2.0 & 1.034 & 0.643 & 0.622 \\
2.5 & 1.052 & 0.539 & 0.512 \\
5 & 1.098 & 0.290 & 0.264 \\
10 & 1.120 & 0.149 & 0.133 \\
100 & 1.125 & 0.015 & 0.013 \\
\hline
\end{tabular}


Table II. Variation of ratio of Coating-Efficiency calculated by eqs. (3) and (2) with column radius, film thickness and inlet to outlet pressure ratio with partition coefficient $K$. (Conditions as in text.) Outlet pressure $P_{0}=1 \mathrm{~atm}$.

\section{(Uniform film distribution)}

\begin{tabular}{|c|l|l|l|c|c|c|c|}
\hline $\begin{array}{c}r \\
\mu \mathrm{m}\end{array}$ & $\begin{array}{l}\mathrm{df} \\
\mu \mathrm{m}\end{array}$ & $\mathrm{a}$ & $\begin{array}{c}\mathrm{P}= \\
\mathrm{P}_{\mathrm{i}} / \mathrm{P}_{0}\end{array}$ & $\mathrm{~K}=100$ & $\mathrm{~K}=1000$ & \multicolumn{3}{|c|}{ Max. } & at $K_{\max }$ \\
\hline 250 & 1 & 0.008 & 1.25 & 1.31 & 1.06 & 1.38 & 37.7 \\
& 0.5 & 0.004 & 1.25 & 1.11 & 1.03 & 1.11 & 75.4 \\
125 & 0.5 & 0.008 & 2 & 1.26 & 1.08 & 1.32 & 37.6 \\
& 0.1 & 0.0016 & 2 & 1.04 & 1.04 & 1.05 & 190 \\
50 & 0.5 & 0.02 & 7.25 & 1.37 & 1.15 & 1.63 & 15 \\
& 0.1 & 0.004 & 7.25 & 1.14 & 1.12 & 1.14 & 75 \\
25 & 0.5 & 0.04 & 26 & 1.30 & 1.13 & 1.71 & 7.6 \\
& 0.1 & 0.008 & 26 & 1.15 & 1.13 & 1.15 & 37.5 \\
\hline
\end{tabular}

Table III. Variation of ratio of Coating-Efficiency calculated by eqs. (3) and (2) with column radius, film thickness at $P_{i} / P_{0}=2$ with partition coefficient $K$. (Conditions as in text.) Outlet pressure $P_{0}=1 \mathrm{~atm}$.

(Uniform film distribution)

\begin{tabular}{|c|c|c|c|c|c|c|c|}
\hline $\begin{array}{c}r \\
\mu \mathrm{m}\end{array}$ & $\begin{array}{l}\mathrm{df} \\
\mu \mathrm{m}\end{array}$ & a & $\begin{array}{r}P= \\
P_{i} / P_{0}\end{array}$ & $K=100$ & $\begin{array}{l}C E(3) / C E \\
K=1000\end{array}$ & Max. & at $K_{\max }$ \\
\hline \multirow[t]{2}{*}{50} & 0.5 & 0.02 & 2 & 1.71 & 1.14 & 2.29 & 15 \\
\hline & 0.1 & 0.004 & 2 & 1.11 & 1.05 & 1.11 & 75 \\
\hline \multirow[t]{2}{*}{25} & 0.5 & 0.04 & 2 & 2.31 & 1.14 & 4.23 & 7.6 \\
\hline & 0.1 & 0.008 & 2 & 1.26 & 1.08 & 1.32 & 37.5 \\
\hline
\end{tabular}

In preparing Tables II and III the following assumptions have been made:

a) the partition coefficient $\mathrm{K}$ is considered to be independent of pressure, this is only true for not too high values of the average column pressure,

b) in Table II the pressure drops have been selected such that the pressure drop, $\Delta \mathrm{P}$, is proportional to $1 / \mathrm{r}^{2}$. This means that under optimum conditions the columns of different radius have very roughly about the same plate number.

In the last two rows of Tables II and III the maximum values of $\mathrm{CE}(3) / \mathrm{CE}(2)$ are presented together with the accompanying value of the partition coefficient $K$.

\section{Conclusions}

As can be concluded from Tables II and III the generally accepted expression for the coating-efficiency $\mathrm{CE}(2)$ is an unacceptable oversimplification in many cases. The coatingefficiency following from eq.(3) is always larger than $C E(2)$. There is no sound reason for neglecting the $C_{s}$ term with respect to the $\mathrm{C}_{\mathrm{m}, 0}$ term, in most practical situations. In situations of large inlet to outlet pressure ratios the pressure correction factors $f_{1}$ and $f_{2}$ should be included also in the calculations.

The authors feel that the column efficiency, as observed in practice, should be compared with values obtained from a complete theoretical treatment. Only in this way valuable 
information can be obtained on the actual distribution of the liquid phase in the column.

An expression (6) is introduced which enables research scientists to obtain the theoretical value of the C.E, without need of simplifying assumptions. From eq. (6) the errors involved in using the simplified equation can easily be deduced, provided $D_{s}$ and $D_{m, 0}$ are known. Eq. (6) can explain the observations mentioned in the introduction when using the simplified expression, (2), via the effects of:

- phase ratio solute retention

- nature of carrier gas

- column outlet pressure

- inlet to outlet pressure ratio

- nature and distribution of liquid phase

- column temperature.

As can be concluded from Tables II and III a large pressure gradient, or large value of $P$, partly compensates the effect of a non-negligible $\mathrm{C}_{\mathrm{s}}$-term.
Hopefully in the near future more data on diffusion in liquid phases will become available. If so the $C_{s}$ term for uniform film distribution and thus eq. (6) can be calculat. ed exactly. Then, deviations from a coating-efficiency from $100 \%$ (acc. to eq. (3)) will give important information on the actual distribution of the liquid phase, and thus enable researchers to point their attention to this now often neglected aspect in developing the ideal column.

\section{References}

[1] C. A. Cramers, F. A. Wijnheijmer and J. A. Rijks, J. High Res. Chromatogr., to be published.

[2] M. Golay in "Gas Chromatography, 1958", Butterworth, ed. D. H. Desty, London, 1959, p. 36.

[3] J. C. Giddings, Anal. Chem. 36, 741 (1964).

[4] D. H. Desty and A. Goldup in "Gas Chromatography 1960", Butterworth, ed. R. P. W. Scott, London, 1960, p. 162-163.

Received: May 9,1979 Accepted: May 22, 1979 